\title{
PENGARUH STRES KERJA, MOTIVASI KERJA, PELATIHAN KERJA TERHADAP KINERJA GURU
}

\author{
Imam Rosyadi \\ Imam.rosyadi@gmail.com \\ Program Studi Manajemen Informatika, Universitas Muhammadiyah Pekajangan Pekalongan
}

\begin{abstract}
Abstrack
The purpose of this research is to know influence of work stres, work motivation and training to good teacher performance simultaneously and partial also to know dominant variable than influence the teacher performance. SMK Gondang is the researcher location with 57 teachers as respondent. Data analysis techniques used to test the hypothesis is couple linear regression analysis that has a purpose to know the simultaneous and partial influences also to determine dominant variable that influences teacher performance. Based on the analysis result we know that work stres variable, work motivation and traning significant simultaneously to SMK Gondang teacher performance with contribution number is 91,6 percent. Stres variable, work motivation and training has positive influences and significant partially to employee performance at SMK Gondang with variable motivation work as the most influence variable to teacher performance.
\end{abstract}

Keywords: Work stress; Work Motivation; Training; and Teacher Performance

\begin{abstract}
Abstrak
Penelitian ini adalah untuk mengetahui apakah pengaruh stres kerja, motivasi kerja dan pelatihan terhadap kinerja guru, baik secara simultan dan parsial sehingga dapat mengetahui variabel dominan dari pengaruh kinerja guru. Penelitian ini dilaksanakan di SMK Gondang Pekalongan. SMK Gondang Pekalongan adalah lokasi peneliti dengan 57 guru sebagai responden. Teknik analisis data yang digunakan untuk menguji hipotesis adalah analisis regresi linier berganda yang bertujuan untuk mengetahui pengaruh simultan dan parsial juga untuk mengetahui variabel dominan yang mempengaruhi kinerja guru. Berdasarkan hasil analisis diketahui bahwa variabel stres kerja , motivasi kerja dan traning signifikan secara simultan terhadap kinerja guru SMK Gondang dengan jumlah kontribusi 91,6 persen. Variabel stres kerja , motivasi kerja dan pelatihan memiliki pengaruh positif dan signifikan secara parsial terhadap kinerja karyawan di SMK Gondang dengan variabel motivasi kerja sebagai variabel yang paling berpengaruh terhadap kinerja guru.
\end{abstract}

\section{Kata Kunci: Stres kerja; Motivasi Kerja; Pelatihan; dan Kinerja Guru}




\section{PENDAHULUAN}

Guru menurut UU No.14 tahun 2005: guru adalah pendidik, mengajar, membimbing, mengarahkan, melatih, menilai dan mengevaluasi peserta didik pada pendidikan anak usia dini jalur pendidikan formal, pendidikan dasar, dan pendidikan men-engah.

Tentang guru tersebut dapat di buktikan berdasarkan survey awal yang dilakukan penulis pada tanggal 1 Agustus 2019 di SMK Gondang, penulis dengan data ada sebagian guru yang belum menunjukan kinerja yang baik seperti: guru mengajar tanpa persiapan yang baik, guru ada yang datang terlambat masuk kelas, guru tidak bisa mengendalikan situasi kelas yang ribut.

Berdasarkan uraian diatas maka penulis tertarik untuk melakukan penelitian dengan judul "Pengaruh Stres Kerja, Motivasi Kerja Dan Pelatihan Terhadap Kinerja Guru Di SMK Gondang”.

\section{TINJAUAN PUSTAKA}

\section{Teori Harapan ( Expectancy Theory)}

Teori Harapan ini merupakan akibat suatu hasil dari yang ingin dicapai oleh seorang dan perkiraan yang bersangkutan bahwa tindakannya akan mengarah kepada hasil yang diinginkannya itu. Artinya, apabila seseorang sangat menginginkan sesuatu, dan jalan tampaknya terbuka untuk memperolehnya, yang bersangkutan akan berupaya mendapatkannya (Ahmad Soedrajat, 2015).

\section{Kerangka Berpikir}

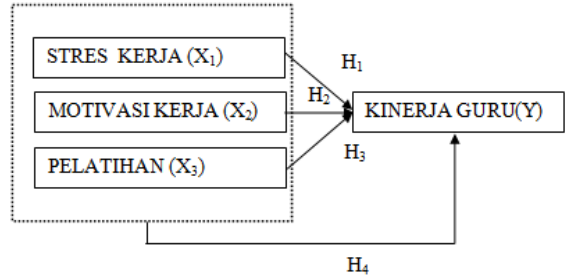

\section{Gambar 1 \\ Kerangka Pemikiran Teoritis}

\section{Hipotesis Penelitian}

Berdasarkan kerangka pemikiran tersebut maka hipotesis dalam penelitian ini sebagai berikut:

H1=Diduga Stres kerja berpengaruh signifikan terhadap kinerja guru.

H2=Diduga Motivasi kerja berpengaruh signifikan terhadap kinerja guru.

H3=Diduga Pelatihan berpengaruh signifikan terhadap kinerja guru.

H4=Diduga stres kerja, motivasi kerja dan pelatihan secara bersama-sama berpengaruh signifikan terhadap kinerja guru.

\section{METODE PENELITIAN}

\section{Desain Penelitian}

Pada penelitian ini variabel independen adalah Stres kerja, motivasi kerja, dan pelatihan. Sedangkan variabel dependen adalah kinerja guru.

\section{Populasi dan Sampel}

Populasi dari penelitian ini adalah guru SMK Gondang Wonopringgo yakni yang berjumlah 57 orang berdasarkan dari data yang diperoleh dari pihak sekolah.

\section{Analisis Regresi Linier Berganda}

Rumus matematis dari regresi berganda yang digunakan dalam penelitian ini adalah :

$$
\mathbf{Y}=\mathbf{a}+\mathbf{b}_{1} \mathbf{X}_{1}+\mathbf{b}_{2} \mathbf{X}_{2}+\mathbf{b}_{3} \mathbf{X}_{3}+e
$$

Keterangan :

$\mathbf{Y} \quad=$ Kinerja guru

A $=$ constanta 
Indonesian Journal Of Strategic Management

Vol 3, Issue 1, february 2020

DOI: https://doi.org/10.25134/ijsm.v2i1.1855

$\mathbf{b}_{1} \quad=$ Koefisien regresi antara stres kerja dengan kinerja guru

$\mathbf{b}_{2} \quad=$ Koefisien regresi antara motivasi kerja dengan kinerja guru

b3 = Koefisien regresi antara pelatihan dengan kinerja guru

$\mathbf{X}_{\mathbf{1}} \quad=$ Variabel stres kerja

$\mathbf{X}_{\mathbf{2}}=$ Variabel motivasi kerja

$\mathbf{X}_{\mathbf{3}}=$ Variabel pelatihan

$\mathbf{E}=$ error disturbance

\section{HASIL DAN PEMBAHASAN}

\section{Teknik Analisis}

\section{Uji Regresi Linier Berganda}

Dari hasil perhitungan dengan bantuan software SPSS. Diperoleh persamaan regresi sebagai berikut:

Tabel 16

Hasil Uji Linier Berganda Dependent Variable: Kinerja Guru

\begin{tabular}{|c|c|c|c|c|c|c|}
\hline \multirow{2}{*}{\multicolumn{2}{|c|}{ Model }} & \multicolumn{2}{|c|}{$\begin{array}{c}\text { Unstandardized } \\
\text { Coefficients }\end{array}$} & \multirow{2}{*}{\begin{tabular}{|c} 
Standardized \\
Coefficients \\
Beta
\end{tabular}} & \multirow[t]{2}{*}{$t$} & \multirow[t]{2}{*}{ Sig. } \\
\hline & & $B$ & Std. Error & & & \\
\hline \multirow[t]{5}{*}{1} & $($ Constant $)$ & -4.020 & 1.382 & & -2.909 & .005 \\
\hline & Stres Kerja & .116 & .045 & .101 & 2.571 & .013 \\
\hline & Motivasi & & & $60 ?$ & 667 & \\
\hline & Kerja & & & & 0.072 & \\
\hline & Pelatihan & .450 & .114 & .358 & 3.963 & .000 \\
\hline
\end{tabular}

Persamaan regresi

$\mathrm{Y}=-4.020+0,116 \mathrm{X} 1+0,948 \mathrm{X} 2+0,450$ $\mathrm{X} 3+\mathrm{e}$

\section{Uji Hipotesi}

Uji $t$

Tabel 1

Hasil Uji t Dependent Variable: Kinerja Guru

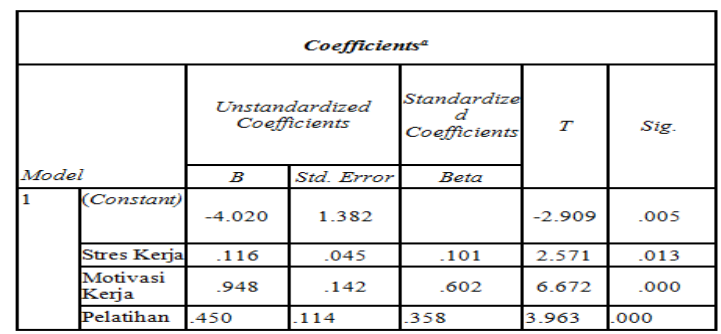

p-ISSN 2614-5391, e-ISSN 2614-2406 https://journal.uniku.ac.id/index.php/ijsm

Sumber: Data primer diolah 2019

\section{Uji F}

Berdasarkan tabel diatas diketahui koefisien uji $f$ sebesar 205,145 dengan nilai signifikansi sebesar $0,000<0,05$. Hal ini menunjukkan bahwa secara simultan, semua variabel independen yaitu stres kerja, motivasi kerja dan pelatihan berpengaruh signifikan terhadap kinerja guru SMK Gondang Wonopringgo.

\section{Uji Koefisien Determinasi}

Berdasarkan tabel diatas dapat diketahui bahwa hasil adjusted RSquare 0,916 atau $91,6 \%$. Hal ini berarti $91,6 \%$ kinerja guru bisa dijelaskan oleh ketiga variabel independen tersebut. Sedangkan sisanya $8,4 \%$ dijelaskan oleh faktor-faktor lain yang tidak dimasukkan atau disebutkan dalam penelitian ini, maka dalam penelitian berikutnya dapat menambahkan variabel independen lain seperti gaya kepemimpinan, upah/gaji, lingkungan kerja untuk meningkatkan nilai koefisien determinasi.

\section{KESIMPULAN}

Dari hasil pengujian hipotesis menunjukkan bahwa variabel Stres kerja $\left(X_{1}\right)$, motivasi kerja $\left(\mathrm{X}_{2}\right)$ dan pelatihan $\left(\mathrm{X}_{3}\right)$ secara bersama-sama berpengaruh signifikan kinerja guru SMK Gondang Wonopringgo (Y). Hal ini menunjukkan bahwa secara simultan, semua variable independen yaitu Stres kerja, motivasi kerja dan pelatihan berpengaruh signifikan terhadap kinerja guru SMK Gondang Wonopringgo. Dalam penelitian ini diperoleh nilai koefisien determinasi sebesar 0,916 atau 91,6\%. Hal ini berarti 91,6\% 
Indonesian Journal Of Strategic Management

Vol 3, Issue 1, february 2020

DOI: https://doi.org/10.25134/ijsm.v2i1.1855

kinerja guru bisa dijelaskan oleh ketiga variabel independen tersebut.

\section{KETERBATASAN PENELITIAN}

Dalam penelitian ini, masih terdapat keterbatasan yang mungkin mempengaruhi hasil penelitian lain, beberapa keterbatasan penelitian ini antara lain: 1) Objek penelitian hanya dilakukan pada sekolah SMK Gondang Wonopringgo sehingga penelitian ini belum mampu menggeneralisasi kinerja guru pada sekolah lainnya; 2) Perlu dilakukan penelitian lebih lanjut terhadap faktor-faktor yang mempengaruhi kinerja guru. Dalam penelitian ini hanya terdiri dari tiga variabel, yaitu stres kerja, motivasi kerja, dan pelatihan sedangkan masih banyak variabel lain yang mempengaruhi kinerja guru; 3) Adanya keterbatasan penelitian dengan menggunakan kuisioner yaitu terkadang jawaban yang diberikan oleh sampel tidak menunjukan keadaan sesungguhnya.

\section{SARAN}

Dengan memperhatikan keterbatasan penelitian yang telah dijelaskan sebelumnya, maka saran untuk penelitian selanjutnya adalah: 1) Peneliti selanjutnya diharapkan dapat menguji model penelitian yang sama dengan objek penelitian di sekolah lain; 2) Penelitian selanjutnya dapat menambah atau memperbaiki pertanyaan-pertanyaan yang ada dalam penelitian ini; 3) Penelitian selanjutnya hendaknya lebih memperbanyak variabel dan memperdalam pembahasan mengenai faktor-faktor yang mempengaruhi kinerja guru seperti halnya variabel gaya kepemimpinan, upah/gaji, lingkungan kerja sehingga dapat menyempurnakan penelitian ini.

\section{IMPLIKASI}

p-ISSN 2614-5391, e-ISSN 2614-2406 https://journal.uniku.ac.id/index.php/ijsm

Hasil penelitian menjelaskan bahwa variabel independen yang terdiri dari stress kerja, motivasi kerja dan pelatihan mempengaruhi kinerja guru di SMK Gondang Wonopringgo. 1) Dari hasil penelitian tersebut dapat disimpulkan bahwa Stres kerja mempunyai dampak yang besar dalam mempengaruhi kinerja seorang guru. Maka SMK Gondang diharapkan agar dapat menerapkan peraturan yang jelas dan memberikan sanksi yang tegas disekolah bisa mengurangi Stres kerja guru sehinga kinerja guru dapat meningkat atau lebih baik; 2) Dari hasil penelitian tersebut dapat disimpulkan bahwa motivasi kerja mempunyai dampak yang besar dalam mempengaruhi kinerja seorang guru; 3) Dari hasil penelitian tersebut dapat disimpulkan bahwa pelatihan mempunyai dampak yang besar dalam mempengaruhi kinerja seorang guru. Hasil penelitian ini dapat dijadikan sebagai pertimbangan bagi sekolah lain tentang kinerja guru bagi sekolah lain

\section{DAFTAR PUSTAKA}

Agustin, E. (2015). Pengaruh Motivasi Terhadap Kinerja Guru Sekolah DASAR Dabin IV Kecamatan Kajen Kabupaten Pekalongan.

Al-Ghozali, I. (2014). Aplikasi Analisis Multivariate dengan Program SPSS.Cetakan IV. Semarang: Badan Usaha Penerbit Undip.

Anwar. P. M. (2014). Evaluasi Kinerja SDM. Bandung: PT. Refika Aditama.

Ardhyaviana, S. (2017) Hubungan Antara Kepuasan Kerha Dengan Motivasi Kerja Pada Karyawan Sales Promotion Girl (SPG) Lapangan.

Depdiknas. (2003). Undang-Undang Republik Indonesia Nomor 20 Tahun 2003 tentang Sistem Pendidikan Nasional. Jakarta: Departemen Pendidikan Nasional.

Edarmayanti. (2014). Manajemen Sumber Daya Manusia Reformasi Birokrasi dan Manajemen Pegawai Negeri Sipil. Bandung : PT. Refika Aditama.

Edison. (2016). Manajemen Sumber Daya Manusia, Bandung : Alfabeta

Edy, S. (2016). Manajemen Sumber Daya Manusia. Jakarta : Kencana.

Hasibuan, M. (2010). Manajemen Sumber Daya Manusia, PT. Bumi Aksara Haji. Jakarta 
Indonesian Journal Of Strategic Management

Vol 3, Issue 1, february 2020

DOI: https://doi.org/10.25134/ijsm.v2i1.1855

Hidayat, E. A. (2017). Pengaruh Kepemimpinan, Komunikasi, Rewards, dan Motivasi Terhadap Kinerja Guru san Karyawan di Madraah Aliyah Negri Rejotangan Tulungagung. Jurnal Manajemen, 06.

Jeine, K. T. (2016). Pengaruh Kompetensi, Disiplin kerja, dan Profesionalisme SMA Negri 1 Manado.

Kasmir. (2016). Manajemen Sumber Daya Manusia. Cetakan Kesatu. Jakarta: PT Rajagrafindo Persada

Mahmudah, L. N. (2017). Pengaruh Pelatihan dan Pengalaman Mengajar Terhadap Kinerja Guru di MTS Negri Karangawen.

Mahmudi, Y. (2016) Kinerja dan Motivasi Guru dalam membentuk Karakter Siswa di SMA Negeri 1 Sekampung, MA Ma"arif 5 Sekampung dan SMK Darurrohmah Kabupaten Lampung Timur.

Mangkunegara, A. A., \& Anwar, P. (2016), Manajemen Sumber Daya Manusia Perusahaan, PT. Remaja Rasdakarya, Bandung.

Mulyasa. (2015). Standar Kompetensi dan Sertifikasi Guru. Bandung: Remaja Posdakarya.

Muniati. (2016). Pengaruh Pendidikan dan Pelatihan terhadap Kinerja Guru di SMK Bungoro Pangkep.

Priansa, D. J. (2014). Kinerja dan Profesionalisme Guru. Bandung: Alfabeta.

Rizal, A. S. (2019). Pengaruh motivasi Kerja dan Disiplin Kerja terhadap Kinerja Guru SMP.

Soekanto, S. (2015) Sosiologi Suatu Pengantar. Jakarta: Rajawali Pers.

Sugiyono. (2017). Metode Penelitian Kualitatif: Untuk penelitian yang bersifat: eksploratif, enterpretif, interaktif, dan konstruktif. Bandung: Alfabeta.

Suparta, L. A. (2016). Pengaruh Kepemimpinan dan Motivasi Kerja terhadap kinerja Guru. Jurnal Ekonomi dan Bisnis.

Suwanto., \& Donni, J. P. (2014). Manajemen SDM Dalam Organisasi Publik dan Bisnis. Bandung : Alfabeta.

Undang-Undang Republik Indonesia Nomor 14 Tahun 2005 tentang Guru dan Dosen. Jakarta: Departemen Pendidikan Nasional.

Undang-undang RI No. 14 Tahun 2005 tentang Guru dan Dosen. Diperbanyak oleh PB PGRI.

Wiwi, W. (2017) Pengaruh Pelatihan dan Lingkungan Kerja Non Fisik terhadap Kinerja Pegawai di Sekretariat Dewan Perwakilan Rakyat Faerah Provinsi Jawa Barat.

Wike, P. (2017) Pengaruh Disiplin dan Motivasi Kerja terhadap Kinerja Karyawan PT. Taspen (PERSERO) Kantor Cabang Utama Bandung.
p-ISSN 2614-5391, e-ISSN 2614-2406

https://journal.uniku.ac.id/index.php/ijsm 